\title{
Shark Cartilage Extract AE-941
}

National Cancer Institute

\section{Source}

National Cancer Institute. Shark Cartilage Extract AE-941. NCI Thesaurus. Code C1798.

A multifunctional antiang iogenic agent derived from shark cartilage with potential antineoplastic activity. Shark cartilage extract AE-941 competitively inhibits the binding of pro-angiog enic vascular endothelial growth factor (VEGF) to its cellular receptor, thereby inhibiting endothelial cell proliferation. This agent also inhibits matrix metalloproteinases (MMPs), stimulates tissue plasminogen activator (tPA), and activates caspase-mediated apoptotic pathways in endothelial cells. 